Accepted Manuscript. The final article was published in: Chemical Communications, 2011,47, 2676-2678 and is available at: https://doi.org/10.1039/C0CC05599A

Cite this: DOI: $10.1039 / \mathrm{c0xx} 00000 x$

www.rsc.org/xxxxxx

ARTICLE TYPE

\title{
X-Ray Crystal Structure of a Heterobimetallic Al-Zn-Oxide Complex
}

\author{
Stephan Schulz,* Jan Spielmann, Dieter Bläser and Christoph Wölper \\ Received (in XXX, XXX) Xth XXXXXXXXX 20XX, Accepted Xth XXXXXXXXX 20XX \\ DOI: $10.1039 / b 000000 x$
}

${ }_{5} \mathrm{OH} / \mathrm{R}(\mathrm{R}=\mathrm{H}, \mathrm{Me}, \boldsymbol{i}$-Bu) exchange was observed in reactions of $[\text { MesnacnacZn }(\mu-O H)]_{2}$ (1) with metal complexes $L_{n} M R$, whereas DippnacnacAl(Me)OH reacts with MesnacnacZnH with elimination of $\mathrm{H}_{2}$ and formation of the heterobimetallic Al-Zn-oxide complex MesnacnacZnOAl(Me)Dippnacnac 2.

10 Heterobimetallic oxides have received growing interest due to their potential to serve as precursors in materials sciences, i.e. the synthesis of spinels $\mathrm{M}^{\mathrm{II}} \mathrm{Al}_{2} \mathrm{O}_{4},[1]$ and catalysis.[2] They are expected to show new reactivity patterns and physical properties due to cooperative effects,[3] which are typical for biological 15 systems such as proteins and which can not be achieved in monometallic systems, [4] and may also serve as a model for the fixation of catalysts on oxide surfaces.[5] Consequently, new synthetic strategies for well-defined heterometallic complexes containing metal centers with entirely different chemical 20 properties were developed. Oxo-bridged Al-O-M complexes (M $=\mathrm{Ti}, \mathrm{Zr}$, Hf) were obtained from reactions of metal hydroxides such as DippnacnacAl(Me)OH with alkyl-substituted metal complexes, i.e. group 4 metallocene and half-metallocene complexes.[6] They exhibit high catalytic activities in olefin 25 polymerization reactions.[7] These studies have been consequently extended to other main group and transition metal and lanthanide complexes,[8] proving its general applicability. In contrast, heterobimetallic complexes with group 12 and group 13 metals are unknown. This is surprising since bimetallic $\mathrm{Zn}$ 30 complexes are living single-site catalysts for the ring-opening polymerization (ROP) of lactide[9] and the epoxides $/ \mathrm{CO}_{2}$ copolymerization,[10] whereas bimetallic $\mathrm{Ca} / \mathrm{Zn}$ complexes catalyze epoxide/anhydride/ $\mathrm{CO}_{2}$ terpolymerization[11] and epoxide $/ \mathrm{CO}_{2}$ copolymerization reactions, respectively.[12]

35 Due to our general interest in organozinc complexes $\mathrm{LZnX}(\mathrm{L}$ $\left.=\left[\mathrm{HC}\left\{\mathrm{C}(\mathrm{Me}) \mathrm{N}\left(2,4,6-\mathrm{Me}_{3} \mathrm{C}_{6} \mathrm{H}_{2}\right)\right\}_{2}\right] \mathrm{X}=\mathrm{H}, \mathrm{R}, \mathrm{OR}\right),[13]$ be began to study the synthesis molecular zinc hydroxides and report herein on the synthesis of a molecular zinc hydroxide $\mathrm{LZnOH} \mathbf{1}$, which we assumed to be a valuable precursor for heterobimetallic 40 oxide complexes, and its reactions with methyl-substituted main group and transition metal complexes. In addition, the synthesis and X-ray crystal structure of the $\mu$-O-bridged complex LZn- $\mu$ $\mathrm{O}-\mathrm{Al}(\mathrm{Me}) \mathrm{L}^{\prime} 2\left(\mathrm{~L}^{\prime}=\left[\mathrm{HC}\left\{\mathrm{C}(\mathrm{Me}) \mathrm{N}\left(2,6-i-\mathrm{Pr}_{2} \mathrm{C}_{6} \mathrm{H}_{3}\right)\right\}_{2}\right]\right)$ is reported.

$\mathrm{LZnOH} 1$ was obtained from reactions of LZnMe or $\mathrm{LZnH}$ 45 with one equivalent of water in THF (scheme 1). The ${ }^{1} \mathrm{H}$ NMR spectrum of 1 showed a singlet at $-0.20 \mathrm{ppm}$ (OH group). Pulsed gradient spin echo (PGSE) diffusion measurements of $\mathbf{1}$ in benzene- $\mathrm{d}_{6}\left(\mathrm{~T}=25^{\circ} \mathrm{C}\right)$ yielded a hydrodynamic radius of 5.90(1)

$\AA$, which is larger than those reported for monomeric $\mathrm{L} ' \mathrm{ZnH}$ ${ }_{50}(5.2(1) \AA),[14] \mathrm{LZnH}(4.96(25) \AA),[13 \mathrm{~b}]$ and LZnMe (4.65(23)

$\AA)$ in toluene- $\mathrm{d}_{8},[13 \mathrm{a}]$ indicating $\mathbf{1}$ to be dimeric in solution.

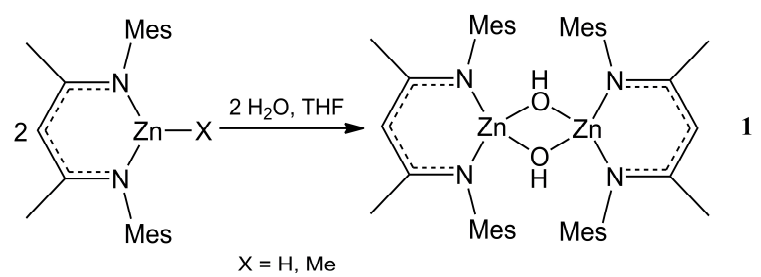

Scheme 1 Synthesis of 1 via hydrolysis of the zinc methyl / hydride complexes

551 shows a strong IR absorption $[v(\mathrm{O}-\mathrm{H})]$ at $3667 \mathrm{~cm}^{-1}$, which corresponds well with values reported for a pyrazolylborate zinc hydroxide $\left(3611 \mathrm{~cm}^{-1}\right)[15]$ and dimeric zinc hydroxides such as $\left[\left(\mathrm{Me}_{2} \mathrm{PhSi}\right)_{3} \mathrm{CZnOH}\right]_{2}\left(3680 \mathrm{~cm}^{-1}\right)[16]$ and NHC-Zn(OMes)OH $\left(3680 \mathrm{~cm}^{-1} ; \mathrm{NHC}=1,3\right.$-bis(2,4,6-trimethylphenyl)imidazol-260 ylidene),[17] whereas the absorption band observed for $\left[\left\{\left(\mathrm{Me}_{3} \mathrm{Si}\right)_{2} \mathrm{CHZn}\right\}_{2}(\mu-\mathrm{OH})\left\{\mu-\mathrm{N}\left(\mathrm{CH}_{2} \mathrm{py}\right)_{2}\right\}\right] \quad\left(3312 \mathrm{~cm}^{-1}\right)[18]$ is shifted to a smaller wave number.

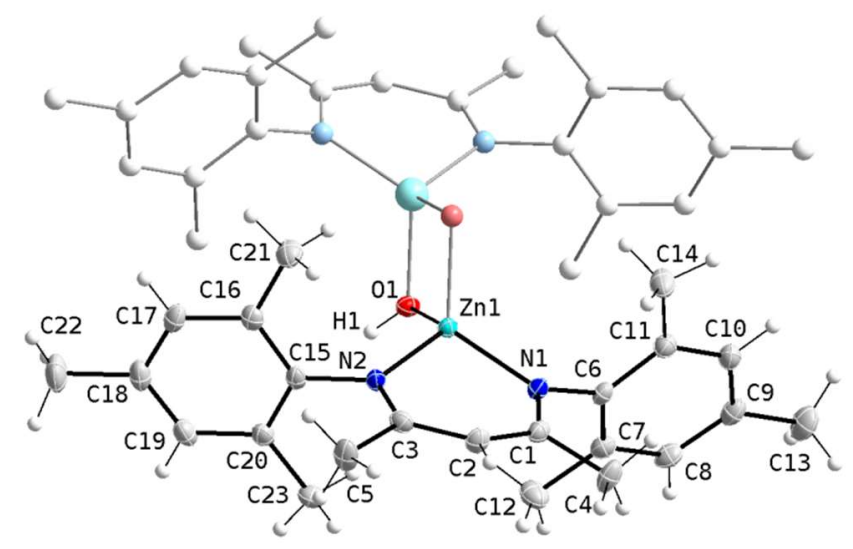

Fig. 1 Solid state structure of 1 (light part generated via inversion); non$65 \mathrm{H}$-atoms shown as thermal ellipsoids at $50 \%$ probability levels (others at arbitrary radii); $\mathrm{H}$ atoms partially omitted for clarity.

1 crystallizes in the triclinic space group $P-1$ with one molecule in the unit cell as a hydroxide-bridged centrosymmetric dimer (figure 1). The $\mathrm{Zn}-\mathrm{O}$ bond lengths in $\mathbf{1}$ are almost identical 70 (Zn1-O1 1.9623(10); Zn1-O1A 1.9890(11) A) as was previously observed for zinc hydroxides, $[10 \mathrm{c}, 16,17,19,20]$ whereas terminal $\mathrm{OH}$ groups show shorter $\mathrm{Zn}-\mathrm{O}$ bond lengths $(1.85-1.90 \AA$ )..[21] The $\mathrm{C}_{3} \mathrm{~N}_{2} \mathrm{Zn}$ ring in $\mathbf{1}$ is planar $(0.109 \AA$ r.m.s. deviation from 
mean plane, 0.0368 for mean plane of $\mathrm{C}$ and $\mathrm{N}$-atoms) with the $\mathrm{Zn}$ atoms slightly out of the mean plane of the $\mathrm{C}$ - and $\mathrm{N}$-atoms (0.4218(17) $\AA$ ). C-C, C-N and $\mathrm{Zn}-\mathrm{N}$ bond lengths within the rings are almost identical compared to the starting complexes 5 LZnH and LZnMe.[13]

1 was reacted with Me-substituted complexes of main group (LiMe, $\left.\mathrm{AlMe}_{3}\right)$ and transition metals $\left(\mathrm{ZnMe}_{2}, \mathrm{Cp}^{*} \mathrm{TiMe}_{3}\right)$. Surprisingly, no gas evolution but only the formation of LZnMe via hydroxide/methyl exchange reaction occurred. This reaction 10 pattern remarkably contrasts that observed for 1,4-dioxane stabilized $\mathrm{EtZnOH}$, which was found to react with $\mathrm{AlMe}_{3}$ with methane/ethane evolution.[23] Moreover, when 1 was reacted with $\mathrm{Al}(i-\mathrm{Bu})_{3}$ and $\mathrm{L}^{\prime} \mathrm{AlH}_{2}$, the formation of $\mathrm{LZn}(i-\mathrm{Bu})$ and $\mathrm{LZnH}$, respectively, was unambigously proved by ${ }^{1} \mathrm{H}$ NMR 15 spectroscopy,[22] while the reaction of $\mathbf{1}$ with $i$ - $\mathrm{Bu}_{2} \mathrm{AlH}$ yielded a mixture of $\mathrm{LZnH}$ and $\mathrm{LZn}(i-\mathrm{Bu})$ in a 5:1 molar ratio according to ${ }^{1} \mathrm{H}$ NMR spectroscopic studies (scheme 2).<smiles></smiles><smiles>[R10][R]([H])(C)CC</smiles>

i) LiMe, $\mathrm{AlMe}_{3}, \mathrm{Cp}^{*} \mathrm{TiMe}_{3}, \mathrm{ZnMe}_{2}$; ii) $i-\mathrm{Bu}_{3} \mathrm{Al}, i-\mathrm{Bu}_{2} \mathrm{AlH}$; iii) L'AlH i) $\mathrm{X}=\mathrm{Me}$; ii) $\mathrm{X}=i-\mathrm{Bu}, i-\mathrm{Bu} / \mathrm{H}$; iii) $\mathrm{X}=\mathrm{H}$

Scheme 2 Reactions of 1 with metal alkyl and hydride complexes

20 Obviously, the Brønsted acidity of the $\mathrm{Zn}-\mathrm{OH}$ group in $\mathbf{1}$ is less pronounced compared to that of $\mathrm{L}^{\prime} \mathrm{Al}(\mathrm{Me}) \mathrm{OH}, \mathrm{L} \cdot \mathrm{Ga}(\mathrm{Me}) \mathrm{OH}$, $\mathrm{L}^{\prime} \mathrm{GeOH}, \mathrm{Cp} 2 \mathrm{Zr}(\mathrm{Me}) \mathrm{OH}$ and [L'Sr(thf)- $\left.\mu-\mathrm{OH}\right]_{2}$, respectively. Our studies demonstrate the distinguished nucleophilicity of $\mathrm{Zn}-\mathrm{OH}$, which is generally accepted for hydrolytic zinc enzymes. 25 Nevertheless, it is remarkable that a $\mathrm{Zn}-\mathrm{OH}$ unit was transformed into a $\mathrm{Zn}$-alkyl and even a $\mathrm{Zn}-\mathrm{H}$ unit by reaction with a metal alkyl or a metal hydride complex such as $\mathrm{L}^{\prime} \mathrm{AlH}_{2}$.

In an attempt to prove the general accessibility of bimetallic zinc oxides, we reacted L'Al(Me)OH with $\mathrm{LZnH}$ (scheme 3). The 30 reaction proceeded with $\mathrm{H}_{2}$-evolution and formation of $\mathrm{LZn}-\mu$-O$\mathrm{Al}(\mathrm{Me}) \mathrm{L}^{\prime} \mathbf{2}$ in almost quantitative yield. An analogous reaction with LZnMe proceeded much slower, gaving $\mathbf{2}$ in less yield, demonstrating $\mathrm{LZnH}$ to be the more reactive species.

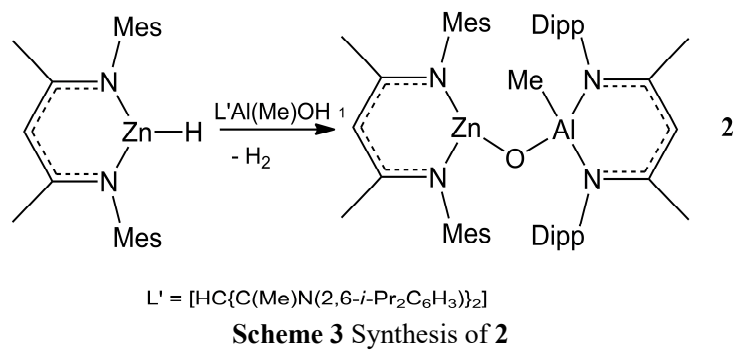

In situ monitoring of the reaction with $\mathrm{LZnH}$ by ${ }^{1} \mathrm{H}$ NMR spectroscopy showed steadily decreasing $\mathrm{Zn}-\mathrm{H}$ and $\mathrm{Al}-\mathrm{OH}$ resonances. The resonances due to the three organic substituents (L, L', Me) in 2 itself show the expected 1:1:1 relative intensity. ${ }_{40} \mathrm{We}$ also reacted $\mathrm{L}^{\prime} \mathrm{Al}(\mathrm{Me}) \mathrm{OH}$ with $\mathrm{L}^{\prime} \mathrm{ZnH}$, but $\mathrm{L}^{\prime} \mathrm{ZnH}$ was found to be less reactive than $\mathrm{LZnH}$, yielding $\mathrm{L} ' \mathrm{Zn}-\mu$-O-Al(Me) $\mathrm{L}^{\prime}$ in low yield together with several by-products.[24] These findings indicate a kinetically controlled reaction pathway, with the less effectively shielded zinc hydride complex LZnH being more 45 reactive than $\mathrm{L}^{\prime} \mathrm{ZnH}$ and $\mathrm{LZn}-\mathrm{Me}$.

2 crystallizes in the monoclinic space group $P 21 / n$ (figure 2). The $\mathrm{Zn}$ atom adopts a distorted trigonal planar coordination sphere with $\mathrm{Zn} 1$ deviating $0.0208(16) \AA$ from the N3/N4/O1 plane. The $\mathrm{N}-\mathrm{Zn}-\mathrm{O}$ angles are slightly larger than $120^{\circ}$ $50\left(128.28(12)^{\circ}, 132.88(11)^{\circ}\right) . \mathrm{Zn} 1$ is off the mean plane of the $\mathrm{C}_{3} \mathrm{~N}_{2}$ central part of the ligand (0.230(4) $\AA$ ) as was observed in $\mathbf{1}$. The $\mathrm{Al}$ atom is distorted tetrahedrally coordinated and All deviates from the mean plane of the $\mathrm{C}_{3} \mathrm{~N}_{2}$ unit by 0.413 (3) $\AA$. The $\mathrm{Zn}-\mathrm{O}$ bond length $(1.782(2) \AA)$ is elongated compared to the Al-O bond ${ }_{55}$ length (1.686(2) $\AA$ ) due to the different covalent radii of $\mathrm{Zn}$ and Al. Analogous structural trends were observed for $\mathrm{Zn}-\mathrm{N}$ (1.950(3), 1.960(3) $\AA$ ) and Al-N bond lengths (1.938(3), 1.918(2) $\AA)$. The N-Al-N bond angle $\left(95.05(11)^{\circ}\right)$ is slightly smaller compared to the N-Zn-N bond angle $\left(98.80(12)^{\circ}\right)$. The C-C-C ${ }_{60}$ backbone angles of the $\beta$-diketiminato ligands were found to be slightly smaller for the Al heterocycle $\left(127.4(3)^{\circ}\right)$ compared to the $\mathrm{Zn}$ heterocycle $\left(130.9(4)^{\circ}\right)$. The Al-O-Zn bond angle of $144.78(15)^{\circ}$ is within the range of $141-176^{\circ}$ observed for oxobridged bimetallic complexes of the general type Al-O-TM (TM ${ }_{65}=$ transition metal).[25]

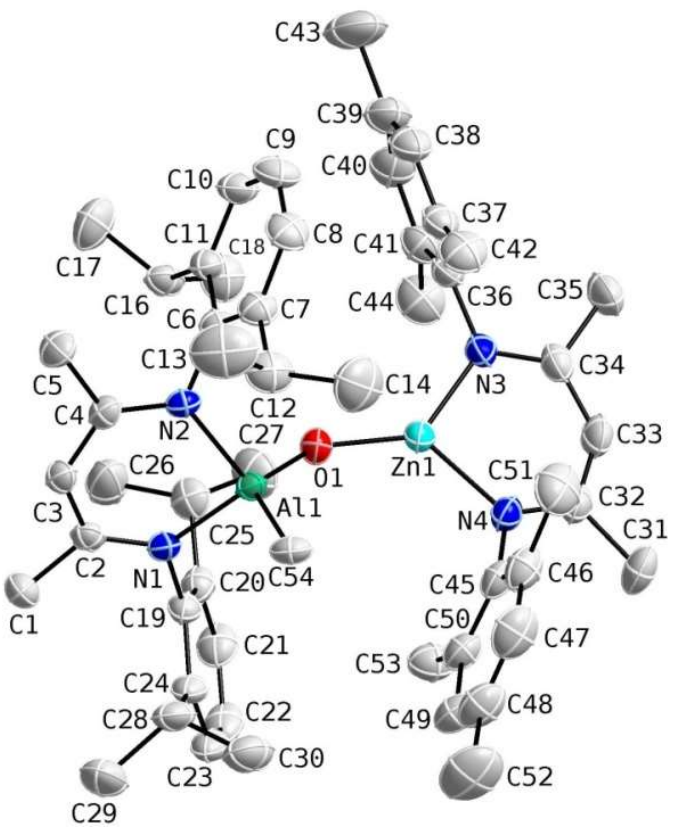

Fig. 2 Solid state structure of $\mathbf{2}$; $\mathrm{H}$ atoms are omitted for clarity, thermal ellipsoids at $30 \%$ probability levels.

The catalytic activity of $\mathbf{2}$ towards $\mathrm{CO}_{2} /$ cyclohexene oxide $70(\mathrm{CHO})$ copolymerization was investigated in neat $\mathrm{CHO}$ with 10 bar $\mathrm{CO}_{2}$ at $50{ }^{\circ} \mathrm{C}$ and a monomer/catalyst ratio of $1000 / 1$. For comparison, the catalytic activities of $\mathrm{LZnH}$ and $\mathrm{L} \cdot \mathrm{Al}(\mathrm{Me}) \mathrm{OH}$ were tested as well, but both showed no catalytic activity. This is not surprising for $\mathrm{LZnH}$, since $\beta$-diketiminate zinc complexes 75 with methyl-sustituents at the 2,6-aryl positions were reported to be inactive in $\mathrm{CO}_{2} / \mathrm{CHO}$ copolymerization reactions.[10a,c] In stoichiometric NMR-scale reactions, $\mathrm{L}^{\prime} \mathrm{Al}(\mathrm{Me}) \mathrm{OH}$ also showed no reaction with $\mathrm{CHO}$ up to $100{ }^{\circ} \mathrm{C}$, whereas the reaction with $\mathrm{CO}_{2}(1 \mathrm{~atm})$ occurred with decomposition of $\mathrm{L}$ 'Al(Me)OH and 
considerable formation of $\mathrm{L}$ 'H. This is probably due to initial formation of the intermediate $\mathrm{L}^{\prime} \mathrm{Al}(\mathrm{Me}) \mathrm{CO}_{3} \mathrm{H}$, containing an acidic $\mathrm{H}$-atom that readily protonates the $\beta$-diketiminato ligand with subsequent formation of $\mathrm{L}$ ' $\mathrm{H}$ and $\mathrm{Al}(\mathrm{Me}) \mathrm{CO}_{3}$. A comparable 5 reactivity is known for the calcium complex $\left[\mathrm{L}^{\prime} \mathrm{CaOH}\right] 2$, also yielding $\mathrm{L}^{\prime} \mathrm{H}$ and $\mathrm{CaCO}_{3}$.[26] Unfortunately, $\mathrm{LZnOAl}(\mathrm{Me}) \mathrm{L}^{\prime} 2$ showed no increased catalytic activity compared to $\mathrm{LZnH}$ and L'Al(Me)OH. To investigate this inactivity in more detail, reactions of 2 with $\mathrm{CO}_{2}$ and $\mathrm{CHO}$ were tested in NMR-scale 10 experiments in deuterated benzene. 2 showed no reaction with $\mathrm{CHO}$ within the temperature range of $20-100{ }^{\circ} \mathrm{C}$, whereas the reaction with $1 \mathrm{~atm} \mathrm{CO}_{2}$ resulted in a clean conversion of $\mathbf{2}$ into a product with a completely new set of ${ }^{1} \mathrm{H}$ NMR signals, indicating that incorporation of $\mathrm{CO}_{2}$ is feasible. The characterization of this 15 new complex is currently under investigation.

\section{Conclusions}

$\mathrm{LZnOH} \mathrm{1,} \mathrm{which} \mathrm{was} \mathrm{prepared} \mathrm{by} \mathrm{controlled} \mathrm{hydrolysis} \mathrm{of} \mathrm{LZnX}$ $(\mathrm{X}=\mathrm{H}, \mathrm{Me})$ with water in THF solution, reacts with alkyl- and hydride-substituted main group and transition metal complexes 20 with $\mathrm{OH} / \mathrm{Y}$ exchange reactions $(\mathrm{Y}=\mathrm{H}, \mathrm{Me}, i-\mathrm{Bu})$ and subsequent formation of $\mathrm{LZnY}$, whereas the more Brønsted acidic $\mathrm{L}$ 'Al(Me)OH reacts with $\mathrm{LZnH}$ with formation of the bimetallic complex L'Al(Me)OZnL 2.

\section{Notes and references}

${ }_{25}$ University of Duisburg-Essen, Universitätsstr. 5-7, S07 S03 C30, 45117 Essen, Germany. Fax: Int (+)201 1833830; Tel: Int (+)201 1834635; Email: stephan.schulz@uni-due.de

$\uparrow$ Electronic Supplementary Information (ESI) available: Full details on the experimental procedures and characterization of $\mathbf{1}$, and $\mathbf{2}$ including 30 single crystal X-ray diffraction, reactivity studies of $[\mathrm{MesnacnacZnOH}]_{2}$ towards $\mathrm{MeLi}, \mathrm{AlMe}_{3}, \mathrm{Al}(i-\mathrm{Bu})_{3}, \mathrm{HAl}(i-\mathrm{Bu})_{2}, \mathrm{Cp}^{*} \mathrm{TiMe}_{3}, \mathrm{ZnMe}_{2}$ and DippnacnacAlH $\mathrm{H}_{2}$ and preliminary experiments on the $\mathrm{CO}_{2} / \mathrm{CHO}$ copolymerization of 2 . See DOI: $10.1039 / \mathrm{b} 000000 \mathrm{x} /$

I CCDC 804558 (1) and 804557 (2) contain the supplementary 35 crystallographic data for this paper. These data can be obtained free of charge from The Cambridge Crystallographic Data Centre via www.ccdc.cam.ac.uk/data request/cif.

1 F. Meyer, R. Hempelmann, S. Mathur and M. Veith, J. Mater. Chem. 1999, 9, 1755; R. C. Mehrotra, Coord. Chem. (IUPAC) 1981, 21,

40 113; V. G. Kessler, S. Gohil and S. Parola, Dalton Trans., 2003, 4, 544.

2 H. W. Roesky, I. Haiduc and N. S. Hosmane, Chem. Rev. 2003, 103 2579; T. Carofiglio, C. Floriani, M. Rosi, A. Chiesi-Villa and C. Rizzoli, Inorg. Chem. 1991, 30, 3245; M. S. Rau, C. M. Kretz, G. L.

45 Geoffroy, A. L. Rheingold and B. S. Haggerty, Organometallics 1994, 13, 1624; H. Li, M. Eddaoudi, J. Plévert, M. O’Keeffe and O. M. Yaghi, J. Am. Chem. Soc. 2000, 122, 12409.

3 B. G.; Ueland, G. C. Lau, R. J. Cava, J. R. O'Brien and P. Schiffer, Phys. Rev. Lett. 2006, 96, 027216.

504 N. Wheatley and P. Kalck, Chem. Rev. 1999, 99, 3379; R.-J. Tao, F.A. Li, S.-Q. Zang, Y.-X. Cheng, Q.-L. Wang, J.-Y. Niu and D.-Z. Liao, J. Coord. Chem. 2006, 59, 901.

5 C. Copéret, M. Chabanas, R. P. Saint-Arroman and J.-M. Basset, Angew.Chem. Int. Ed. 2003, 42, 156.

${ }_{55} 6$ G. Bai, S. Singh, H. W. Roesky, M. Noltemeyer and H.-G. Schmidt, J. Am. Chem. Soc. 2005, 127, 3449; Y. Yang, T. Schulz, M. John, Z. Yang, V. M. Jiménez-Pérez, H. W. Roesky, P. M. Gurubasavaraj, D. Stalke and H. Ye, Organometallics 2008, 27, 769; P. M. Gurubasavaraj, S. K. Mandal, H. W. Roesky, R. B. Oswald, A. Pal and M. Noltemeyer, Inorg. Chem. 2007, 46, 1056; P. M. Gurubasavaraj, H. W. Roesky, B. Nekoueishahraki, A. Pal and R. Herbst-Irmer, Inorg. Chem. 2008, 47, 5324
7 For a very recent review article see: S. K. Mandal and H. W. Roesky, Acc. Chem. Res. 2010, 43, 248.

${ }_{65} 8$ S. Singh, V. Jancik, H. W. Roesky and R. Herbst-Irmer, Inorg. Chem. 2006, 45, 949; S. Nembenna, H. W. Roesky, S. K. Mandal, R. B. Oswald, A. Pal, R. Herbst-Irmer, M. Noltemeyer and H.-G. Schmidt, J. Am. Chem. Soc. 2006, 128, 13056; S. Nembenna, S. Singh, A. Jana, H. W. Roesky, Y. Yang, H. Ye, H. Ott and D. Stalke, Inorg. Chem. 2009, 48, 2273; Y. Yang, H. W. Roesky, P. G. Jones, C.-W. So, Z.; Zhang, R.; Herbst-Irmer and H. Ye, Inorg. Chem. 2007, 46, 10860; J. Chai, V. Jancik, S. Singh, H. Zhu, C. He, H. W. Roesky, H.-G. Schmidt, M. Noltemeyer and N. S. Hosmane, J. Am. Chem. Soc. 2005, 127, 7521 .

759 M. H. Chisholm, J. C. Gallucci and K. Phomphrai, Inorg. Chem. 2005, 44, 8004; A. P. Dove, V. C. Gibson, E. L. Marshall, A. J. P. White and D. J. Williams, J. Chem. Soc., Dalton Trans. 2004, 570; L. R. Rieth, D. R. Moore, E. B. Lobkovsky and G. W. Coates, J. Am. Chem. Soc. 2002, 124, 15239; M. H. Chisholm, J. C. Huffman and K. 80 Phomphrai, J. Chem. Soc., Dalton Trans. 2001, 222; B. J. O'Keefe, M. A. Hillmeyer and W. B. Tolman, J. Chem. Soc., Dalton Trans. 2001, 2215; M. Cheng, A. B. Attygalle, E. B. Lobkovsky and G. W. Coates, J. Am. Chem. Soc. 1999, 121, 11583. For a review article see: J. Wu, T.-L. Yu, C.-T. Chen and C.-C. Lin, Coord. Chem. Rev. 2006, 250, 602 .

10 D. R. Moore, M. Cheng, E. B. Lobkovsky and G. W. Coates, J. Am. Chem. Soc. 2003, 125, 11911; D. R. Moore, M.Cheng, E. B. Lobkovsky and G. W. Coates, Angew. Chem., Int. Ed. 2002, 41, 2599; M. Cheng, D. R. Moore, J. J. Reczek, B. M. Chamberlain, E. B. Lobkovsky and G. W. Coates, J. Am. Chem. Soc. 2001, 123, 8738; B. Y. Liu, C. Y. Tian, L. Zhanq, W. D. Yan and W. J. Zhanq, J. Polym. Sci. Part A: Polym. Chem. 2006, 44, 6243; M. Kröger, C. Folli, O. Walter and M. Döring, Adv. Synth. Cat. 2006, 348, 1908.

11 R. C. Jeske, J. M. Rowley and G. W. Coates, Angew. Chem., Int. Ed. 2008, 47, 6041.

12 D. F.-J. Piesik, S. Range and S. Harder, Organometallics 2008, 27, 6178.

13 S. Schulz, T. Eisenmann, D. Bläser and R. Boese, Z. Anorg. Allg. Chem. 2009, 635, 995; S. Schulz, T. Eisenmann, D. Schuchmann, M. 100 Bolte, M. Kirchner, R. Boese, J. Spielmann and S. Harder, Z. Naturforsch. 2009, 64b, 1397.

14 J. Spielmann, D. Piesik, B. Wittkamp, G. Jansen and S. Harder, Chem. Commun. 2009, 3455.

15 A. Looney, R. Han, I. B. Gorrell, M. Cornebise, K. Yoon, G. Parkin and A. L. Rheingold, Organometallics 1995, 14, 274.

16 S. S. Al-Juaid, N. H. Buttrus, C. Eaborn, P. B. Hitchcock, A. T. L. Roberts, J. D. Smith and A. C. Sullivan, J. Chem. Soc., Chem. Commun. 1986, 908.

17 G. Anantharaman and K. Elango, Organometallics 2007, 26, 1089

11018 E. Jaime, A. N. Kneifel, M. Westerhausen and J. Weston, J. Organomet. Chem. 2008, 693, 1027.

19 M. H. Chisholm, J. C. Gallucci and K. Phomphrai, Inorg. Chem. 2002, 41, 2785; C. Amort, H. Kopacka, B. Bildstein and K. Wurst $Z$. Kristallogr. New Cryst. Struct. 2004, 219, 331

11520 A. M. Arif, A. H. Cowley, R. A. Jones and S. U. Koschmieder J. Chem. Soc., Chem. Commun. 1987, 1319.

21 B. M. Bridgewater and G. Parkin, Inorg. Chem. Commun. 2001, 4, 126; R. Alsfasser, S. Trofimenko, A. Looney, G. Parkin and H. Vahrenkamp, Inorg. Chem. 1991, 30, 4098; M. Ruf and H. Vahrenkamp, Inorg. Chem. 1996, 35, 6571.

22 The reactions were in situ monitored by ${ }^{1} \mathrm{H}$ NMR spectroscopy and the complexes identified by comparing the spectra with those of the known complexes. LZn $(i-\mathrm{Bu})$ was identified by its ${ }^{1} \mathrm{H}$ NMR spectrum, but we could not isolate a pure sample from the reaction product mixture. Details are given in the supporting information file.

23 W. Kuran and M. Czernecka, J. Organomet. Chem. 1984, 263, 1.

24 The complex L'Zn- $\mu$-O-Al(Me)L' couldn't be isolated from the reaction mixture due to similar solubilities of the reaction products.

25 A CSD structural database search (version 5.31 incl. update August 2010) on neutral complexes containing an oxo-bridged Al-O-TM unit $\left(\mathrm{TM}=\right.$ transition metal) revealed 21 entries (mean value $157.3^{\circ}$ ).

26 C. Ruspic, S. Nembenna, A. Hofmeister, J. Magull, S. Harder, H. W. Roesky, J. Am. Chem. Soc. 2006, 128, 15000. 
This text is made available via DuEPublico, the institutional repository of the University of Duisburg-Essen. This version may eventually differ from another version distributed by a commercial publisher.

DOI: $\quad 10.1039 / \mathrm{C} 0 \mathrm{CC} 05599 \mathrm{~A}$

URN: urn:nbn:de:hbz:464-20201110-095744-5

Accepted Manuscript. The final article was published in: Chemical Communications, 2011,47, 2676-2678 and is available at: https://doi.org/10.1039/C0CC05599A 